\title{
Effects of nitrogen fertilizer application rate and time to first harvest on leaf area index; leaf nitrate content and yield of irrigated leaf rape (Brassica napus L. var. Giant)
}

\author{
Masaka, J. ${ }^{1}$, Chandiposha, M. ${ }^{2}$, Makaure, B.T. ${ }^{2}$ \& Mazina, B. ${ }^{2}$ \\ ${ }^{1}$ Department of Land and Water Resources Management, Midlands State University, Private Bag 9055, Gweru, Zimbabwe \\ ${ }^{2}$ Department of Agronomy, Midlands State University, P Bag 9055, Gweru, Zimbabwe \\ Author for correspondence: johnsonmasaka@gmail.com
}

\begin{abstract}
Summary: In Zimbabwe, smallholder cultivation of leaf rape is of considerable importance due to the increasing demand for the leaf veg etable from the rapidly increasing urban populations. A two-season field trial was conducted in the Agricultural Practice Experimental Plots of the Midlands State University in central Zimbabwe. The objective of the study was to establish selected biometric responses of le af rape to $\mathrm{N}$ fertilizer rates and time to first harvesting. Increasing the rate of $\mathrm{N}$ fertilizer application considerably improves the yield of fresh rape leaf; LAI and concentration of leaf nitrate. Delaying rape leaf harvest after $\mathrm{N}$ fertilizer side dressing can be used as a strategy to boost rape leaf yield for vegetable markets with high single delivery demand. When harvesting is deliberately delayed after $\mathrm{N}$ fertilizer application rape LAI are significantly increased. Delaying the first leaf harvests by 7; 14 and 21 days after $\mathrm{N}$ fertilizer side dressing amendments increases the co ntent of nitrate in fresh rape leaves. Fresh rape yield can be more accurately predicted by values of rape LAI. Nitrate concentrations in fresh rape leaf is a po or predictor of rape yield under field conditions.
\end{abstract}

Masaka, J., Chandiposha, M., Makaure, B.T. \& Mazina, B. (2021): Effects of nitrogen fertilizer application rate and time to first harvest on leaf area index; leaf nitrate content and yield of irrigated leaf rape (Brassica napus L. var. Giant). International Journal of Horticultural Science 27: 64-75. https://doi.org/10.31421/ijhs/27/2021/9441

Key words: nitrogen fertilizer, rape crop, leaf quality, leaf yield

\section{Introduction}

The production of leaf vegetables in semi-arid sub-tropical Africa plays important nutritional and income augmentation roles for smallholder farmers (Kuntashula et al., 2004; Nyakudya et al., 2010). The high nutritional value of leafy vegetables plays a pivotal role in the prevention of malnutrition that is common in poor African rural communities (Masaka \& Ndhlovu, 2007). In sub-tropical Africa rape or canola (Brassica napus, L) is grown as a leaf vegetable renowned for its fast growth and early horticultural maturity (De Lannoy, 2001; Nyakudya et al., 2010). Rape, which is grown all year round under smallholder irrigation in Zimbabwe, has long been established in sub-tropical African rural communities as a vital food that is consumed as fresh and dried leaves with starch staples (Oldham, 1999; Nyakudya et al., 2010).

The leaf rape crop is reported in various studies to have an elevated demand for $\mathrm{N}$ and a decreased fertilizer nitrogen use efficiency (Schjoerring et al., 1995; Hirel et al., 2007; Maereka et al., 2007; Avice \& Etienne, 2014; Bouchet et al., 2016). Related studies on mineral nutrition of rape have arrived at the conclusion that the absorption of $\mathrm{N}$ absorption is considerably faster than it is incorporated for growth and development by vegetable plants. This resultantly causes nitrate build-up in the leaf tissue as N reserve (Hirel et al., 2007; Anjum et al., 2012; Bouchet et al., 2016; Li et al., 2016).

The excessive presence of nitrate in rape leaves is detrimental to rape leaf quality and human health (Rossato et al., 2002). Amongst the two forms of available $\mathrm{N}$ in soils, the nitrate
$\mathrm{N}$ is the most critical form in leaf vegetables due to the possibility of nitrate toxicity to human population and domestic animals (Stopes et al., 1989). It is reported that nitrate causes bitterness in rape leaves, making them less acceptable for consumption (McCall \& Willumsen, 1998; Maereka et al., 2007; Gonzalez et al., 2016).

The early stages of rape leaf growth are characterized by the synthesis of the photosynthetic matter and the enlargement of leaves which both demand a large quantity of $\mathrm{N}$ (Johnson et al., 2010; Kusumi et al., 2010). When there is lack of $\mathrm{N}$ the division of cells and their expansion are considerably reduced thereby impacting on the resultant leaf area (Roggatz et al., 1999). The change in dry matter accumulation by the rape crop is strongly influenced by leaf area (LA) and leaf area index (LAI) (Kusumi et al., 2010). The size of rape leaves is determined by the nutritional status of the soil in which the plant is growing (Reid, 2002).

A wide range of studies have confirmed that leaf vegetables are major contributors of dietary nitrate, with significant variations in the content of leaf nitrate content that have harmful effects on the health of humans (Brown et al., 1999; Bouchet et al., 2016). The current study is a critical examination of the agronomic factors that can be employed to modulate yield and nitrate levels in a fresh leaf rape. Specifically, the study was undertaken in order to evaluate the effect of $\mathrm{N}$ fertilizer application rates and the temporal harvest gap after $\mathrm{N}$ fertilizer 
application on leaf area index, leaf nitrate content and yield of irrigated rape.

\section{Materials and methods}

\section{Description of the study site}

The current study was carried out during the dry winter seasons of 2014 and 2015 in the Agricultural Practice Experimental Plots of the Midlands State University $\left(19^{\circ} 25^{\prime} \mathrm{S}\right.$, $29^{\circ} 50^{\prime} \mathrm{E} 19^{\circ} 17^{\prime} \mathrm{S} ; 2^{\circ} 21^{\prime} \mathrm{E}, 1425 \mathrm{~m}$ above sea level) in central Zimbabwe (Figure 1). The site is located in Agro-ecological Region III where total rainfall ranges from 650 to $800 \mathrm{~mm}$ per year (average $725 \mathrm{~mm}$ ). The average annual temperature is $21.6^{\circ} \mathrm{C}$ with infrequent frost occurrence in the months of June and July. Generally, climatic conditions have dry winter and wet summer seasons. The winter dry season covers the period from April to September. The wet summer season extends from the month of October ending in March (Vincent \& Thomas, 1960). The soil is classified as a Ferric Luvisol (FAO-ISS-ISRIC, 1998). The production of vegetables at the experimental site is all year round (De Lannoy, 2001).

\section{Characterization of experimental soil}

The soil at the experimental site is a deeply weathered loamy clay topsoil over clay subsoil derived from gneissic granite. The soil samples were collected using a soil auger. Ten soil samples were obtained from randomly chosen points of the experimental site from depths of 0 to 20; 20 to 60 and 60 to $100 \mathrm{~cm}$ of soil. The soil was then placed in a clean plastic bucket where it was thoroughly mixed in order to obtain a composite soil sample. The composite soil sample was air-dried, and sieved $(<2 \mathrm{~mm})$ for characterization (Table 1). The soil organic content was determined using the Walkely and Black procedure (Nelson \& Sommers, 1996). The Bouyocous hydrometer method (Bouyoucos, 1965) was employed to establish the soil textural classes. About $15 \mathrm{~g}$ of the composite soil sample was placed in $200 \mathrm{ml}$ honey jar where $75 \mathrm{ml} 0.1 \mathrm{M} \mathrm{CaCl}_{2}$ were carefully added and shaken thoroughly using the mechanical method for about 30 minutes. The $\mathrm{pH}$ of the soil sample was determined using a digital pH meter (Model: Orion 701, Orion Manufacturing, MI, USA). The total content of $\mathrm{N}$ was established using the Kjeldahl procedure in which concentrated $\mathrm{H}_{2} \mathrm{SO}_{4} ; \mathrm{K}_{2} \mathrm{SO}_{4}$ and $\mathrm{HgO}$ were used to digest the sample (Bremner, 1996). The Black \& Hartge (1986) method was employed to determine the soil bulk density values.

\section{Cultural practices for the rape seedlings in float trays}

Two rape seeds (cv. English Giant, National Tested Seeds of Zimbabwe) were planted in each cell of 10 polystyrene float trays filled with pine bark growing media under greenhouse conditions in May 2014 and 2015. Seedling emergence in float trays was observed 5-10 days after planting. The seedling thinning exercise was carried out in float trays at four days after seedling emergence ensuring that one healthy seedling remained in each cavity. The rape seedlings were liquid fed with ammonium nitrate $(34.5 \% \mathrm{~N})$, single super phosphate $(20 \%$ $\left.\mathrm{P}_{2} \mathrm{O}_{5}\right)$ and muriate of potash $\left(60 \% \mathrm{~K}_{2} \mathrm{O}\right)$ mixed at a ratio of 3:2:1. The seedlings were then hardened for one week by reducing the frequency of watering gradually from three times to once per day using a watering cane with a fine rose. The seedlings were transplanted from the float trays to the field at 28 days after germination.

\section{Plots establishment}

The field experiments were conducted from April to July for two seasons in 2014 and 2015. The land was cultivated manually to a depth of about $30 \mathrm{~cm}$ and then leveled using a rake. Twentyfour raised plots, which measured 330 by $180 \mathrm{~cm}$, were carefully marked out. Twenty $\mathrm{cm}$ high ridges were put in place around each plot in order to avoid cross-contamination by surface run-off.

\section{Treatments, design and management of experimental crop}

Two experiments constituted the field trial. Experiment 1 was conducted to establish the effect of side dressing $\mathrm{N}$ application rate on leaf area index, leaf nitrate content and yield of leaf rape harvested at weekly interval. Experiment 2 was conducted to determine the effect of the first leaf harvesting time after side dressing $\mathrm{N}$ on leaf area index, leaf nitrate content and yield of leaf rape of the first leaf harvest conducted (42 DAT); 2 (49 DAT) and 3 (56 DAT) weeks after side dressing $\mathrm{N}$. In both experiments $\mathrm{N}$ fertilizer side dressing was applied as ammonium nitrate (AN) $(34.5 \% \mathrm{~N})$ at 35 days after transplanting (DAT). There were four treatments $(\mathrm{N}$ fertilizer application rates) in both experiments replicated three times. Twelve plots were allocated to each experiment. Consequently, there were twenty-four plots in the two experiments.

A randomized complete block design was employed in the field experiments. Five rows of seedlings were planted with spacing in the inter-row of $30 \mathrm{~cm}$ and $30 \mathrm{~cm}$ in the intra-row, giving a plant population of 84175 plants ha $^{-1}$ (50 plants per plot).

Experiment 1 had four treatments laid out as follows:

- $0 \mathrm{~kg} \mathrm{~N} \mathrm{ha}^{-1}$ and weekly leaf harvesting (control, treatment $1)$.

- $50 \mathrm{~kg} \mathrm{~N} \mathrm{ha}^{-1}$ and weekly leaf harvesting (treatment 2).

- $100 \mathrm{~kg} \mathrm{~N} \mathrm{ha}^{-1}$ and weekly leaf harvesting (treatment 3).

- $200 \mathrm{~kg} \mathrm{~N} \mathrm{ha}^{-1}$ and weekly leaf harvesting (treatment 4).

Experiment 2 had four treatments laid out as follows:

- $0 \mathrm{~kg} \mathrm{~N}$ ha-1 and first leaf harvesting 1, 2 and 3 weeks after side dressing (control, treatment 1).

- $50 \mathrm{~kg} \mathrm{~N}$ ha-1 and first leaf harvesting 1, 2 and 3 weeks after side dressing (treatment 2).

- $100 \mathrm{~kg} \mathrm{~N}$ ha-1 first leaf harvesting 1,2 and 3 weeks after side dressing (treatment 3 ).

- $200 \mathrm{~kg} \mathrm{~N}$ ha-1 and first leaf harvesting 1, 2 and 3 weeks after side dressing (treatment 4).

In Zimbabwe, leaves of the leaf rape are harvested from week five (5) after transplanting (Figure 2). The duration of the harvesting period is six weeks (42 days). A basal fertilizer application of compound $\mathrm{S}$ fertilizer $\left(9 \% \mathrm{~N}, 17 \% \mathrm{P}_{2} \mathrm{O}_{5}, 5 \% \mathrm{~K}_{2} \mathrm{O}\right.$ and $7 \% \mathrm{~S}$ ) was done in each treatment during land preparation at a rate of $500 \mathrm{~kg} \mathrm{ha}^{-1}$.

The transplants were sprayed with methomex once every 2 weeks after transplanting for management of aphids. The plots were kept weed free by hand hoeing at 3 and 6 weeks after transplanting. Pressure-compensating drip emitters were used to irrigate the plots. The supplementary irrigation was employed to meet the crop water requirements. Rates of irrigation water varied according to weather conditions. 


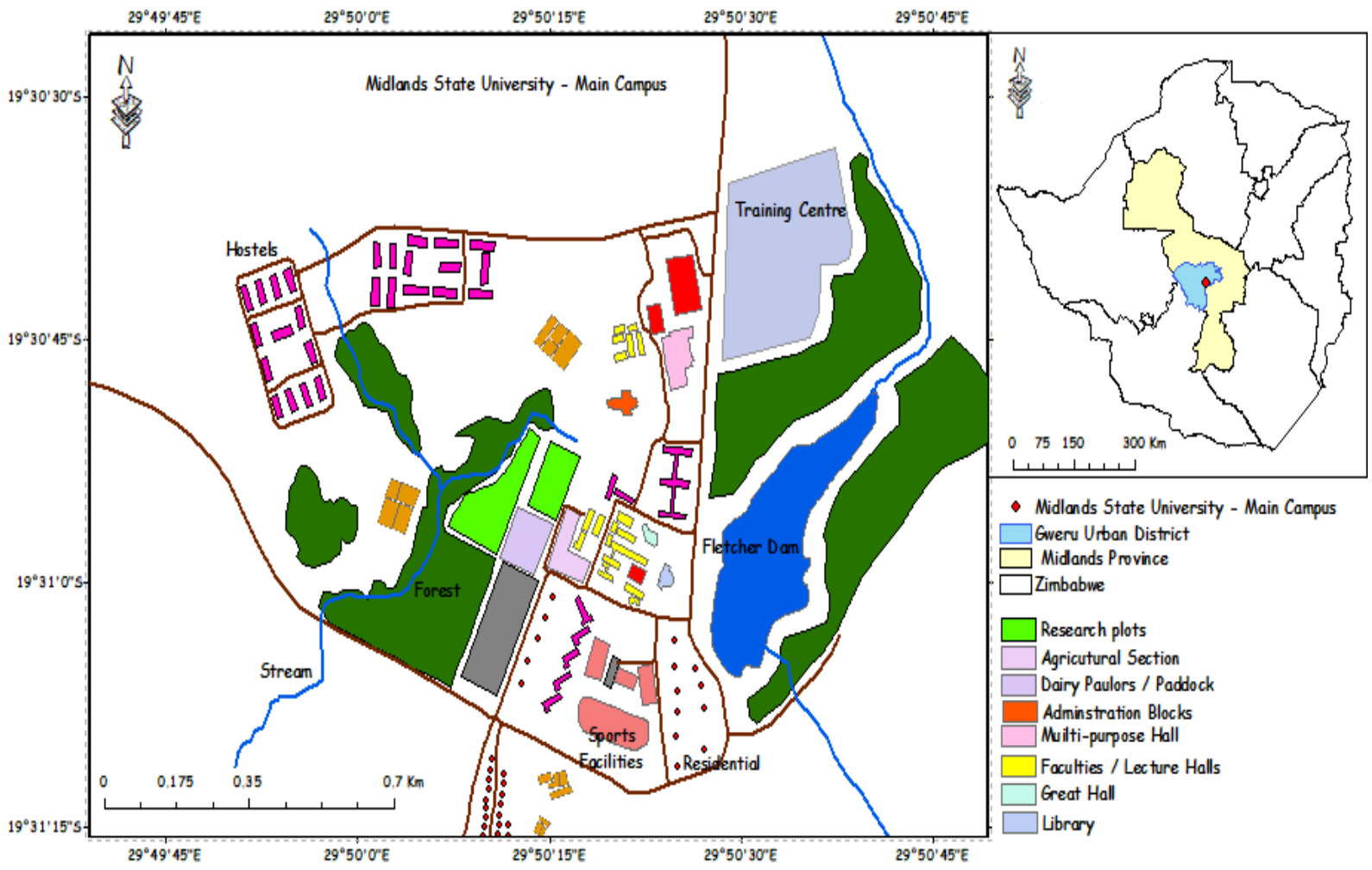

Figure 1. Study site location

Table 1. Chemical and physical properties of the experimental soil

\begin{tabular}{|c|c|c|c|c|c|c|c|c|c|}
\hline $\begin{array}{l}\text { Soil depth } \\
(\mathrm{cm})\end{array}$ & $\begin{array}{l}\text { Soil } \\
\mathrm{pH} \\
\left(\mathrm{H}_{2} \mathrm{O}\right)\end{array}$ & $\begin{array}{l}\text { Org-C } \\
(\%)\end{array}$ & $\begin{array}{l}\mathrm{N} \\
\mathrm{mgkg}^{-1}\end{array}$ & $\begin{array}{l}\text { Sand } \\
(\%)\end{array}$ & $\begin{array}{l}\text { Clay } \\
(\%)\end{array}$ & $\begin{array}{l}\text { Silt } \\
(\%)\end{array}$ & $\begin{array}{l}\text { Total } \\
\text { porosity } \\
\left(\mathrm{cm}^{3} \mathrm{~cm}^{-3}\right)\end{array}$ & $\begin{array}{l}\text { Bulk } \\
\text { density } \\
\left(\mathrm{gcm}^{-3}\right)\end{array}$ & $\begin{array}{l}\text { Saturation } \\
\text { gravimetric } \\
\text { water } \\
\left(\mathrm{gg}^{-1}\right) \\
\end{array}$ \\
\hline $0-20$ & 6.1 & 0.5 & 27 & 75 & 20 & 5 & 0.49 & 1.27 & 0.52 \\
\hline $20-60$ & 6.4 & 0.3 & 22 & 70 & 25 & 5 & 0.44 & 1.32 & 0.66 \\
\hline $60-100$ & 6.5 & 0.1 & 21 & 68 & 30 & 2 & 0.40 & 1.40 & 0.70 \\
\hline
\end{tabular}

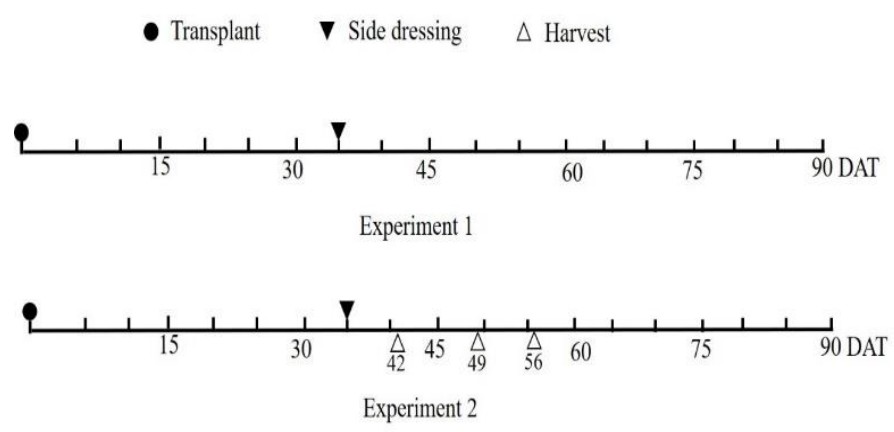

Crop timeline (Days after transplant-DAT)

Figure 2. Timelines of experimental activities over the 90 DAT for experiment 1 and 2

\section{Rape leaf biometric measurements}

In the two experiments, 4 randomly selected rape plants were chosen and labeled in each plot for the biometric measurements. In experiment 1 , rape leaves that reached horticultural maturity from 35 DAT onwards were harvested from the selected rape plants weekly and immediately taken to the laboratory for scaling of fresh rape leaf weight and determination of nitrate content. In experiment 2 , the first harvest of all rape leaves that attained horticultural maturity from the selected plants in the plots was undertaken at one, two, three weeks after $\mathrm{N}$ fertilizer side dressing and subsequent normal leaf harvesting events. The leaf biomass was then immediately taken to the laboratory for scaling of fresh rape leaf and determination of nitrate content. The harvested rape leaves were weighed using a digital scale to obtain fresh leaf weight from each plot.

Fresh leaf harvested biomass for each selected plant in each plot was summed up and converted to yield ha ${ }^{-1}$. Just before each leaf harvesting event, the leaf area index (LAI) was estimated using the LAI-2000 optical instrument (LICOR, Lincoln, USA). The LAI value was established by undertaking a series of 1 above reading and 4 below readings for the selected plants. At each LAI recording event, an opaque mask with a $45^{\circ}$ opening adjusted to the fish-eye lens was employed to reduce the influence of the operator and of the adjacent plots.

A random selection of the biomass collected from each plot produced sub samples which were rinsed; dried in the oven at $70^{\circ} \mathrm{C}$ for $48 \mathrm{hrs}$ and kept in a dry place. The oven-dried biomass sub samples were subjected to grinding into fine powder. The content of nitrate content was established using procedures described by Cataldo et al. (1975). 


\section{Statistical analysis}

A Two-Way ANOVA (GenStat, 2003) was used to analyze treatment effects. Treatment differences between means were considered significant at $\mathrm{p} \leq 0.05$ as determined by Fisher's protected least significant difference test. Change data were logtransformed if needed, to normalize the distributions before the statistical analysis. The separations of means were undertaken using the LSD in each set of experiment. A t-test for unpaired samples was performed using the GenStat package in order to establish statistical significance of the mean differences. Microsoft Excel was used to determine the Pearson correlation coefficients among measured variables and their $r^{2}$ values. A linear model GenStat analysis of correlation at $5 \%$ level was used.

\section{Results}

\section{Experiment 1}

Fresh rape leaf yield over the growing seasons following applications of $N$ fertilizer

Significant differences in the rape fresh leaf yield $(\mathrm{p} \leq 0.05)$ were identified between treatments (Figure 3) in experiment 1. Fresh leaf weights harvested weekly from 42 to 77 DAT (days after transplanting) consistently increased with increasing application rates of mineral $\mathrm{N}$ fertilizer in 2014 and 2015. However, fresh leaf yield harvested from each plot progressively declined towards the last harvest at 77 DAT. Highest leaf yield recordings were observed in the plots subjected to $200 \mathrm{~kg} \mathrm{~N}^{-1}$ side dressing $(1.6-8.4 \mathrm{~T}$ ha ${ }^{1}$ for 2014 and $1.8-8.7 \mathrm{~T} \mathrm{ha}^{-1}$ for 2015).

The increase in $\mathrm{N}$ fertilizer side dressing from 50 to 100 and $200 \mathrm{~kg} \mathrm{~N} \mathrm{ha}^{-1}$ in 2014 and 2015 were followed by elevations of fresh leaf yield ranging from 0.4 to 0.9 and 0.4 to $2.7 \mathrm{~T} \mathrm{ha}^{-1}$ over the harvesting period, respectively. Temporal fresh leaf harvest reductions in the second harvest (49 DAT) compared with the first harvest (42 DAT) ranged from 10.5 to $14.6 \%$ in 2014 in all treatments. In the same year, the last leaf harvests at 77 DAT were 3.69 to $53.8 \%$ lower than the harvests recorded in the second from last harvests (70 DAT) across treatments. Yield reductions consistently fell by larger margins towards the end of the harvesting events for the years 2014 and 2015 (Figure 3).

Content of nitrates in fresh rape leaf over the growing seasons following applications of $N$ fertilizer

Concentrations of nitrates in fresh rape leaf increased consistently $(p \leq 0.05)$ with increasing rates of mineral $\mathrm{N}$ fertilizer side dressing and time of harvesting throughout the study period (Figure 4). When compared with the control the application of $50 ; 100$ and $200 \mathrm{~kg} \mathrm{~N} \mathrm{ha}^{-1}$ as side dressing increased the concentrations of nitrates in fresh leaf vegetable by $0.0721 \mathrm{mg} \mathrm{kg}^{-1}$ or $46.5 \%$; $0.1023 \mathrm{mg} \mathrm{kg}^{-1}$ or $66.0 \%$ and 0.1886 $\mathrm{mg} \mathrm{kg}^{-1}$ or $121.7 \%$ in 2014 and $0.0805 \mathrm{mg} \mathrm{kg}^{-1}$ or $43.1 \%$; 0.1168 $\mathrm{mg} \mathrm{kg}^{-1}$ and $0.1597 \mathrm{mg} \mathrm{kg}^{-1}$ or $85.5 \%$ in 2015 over that in control plots, respectively.

When the application of $\mathrm{N}$ was increased from 50 to $100 \mathrm{~kg}$ $\mathrm{N} \mathrm{ha}^{-1}$ the concentrations of nitrates in fresh rape leaf correspondingly increased by 0.0302 and $0.0363 \mathrm{~kg} \mathrm{~N} \mathrm{ha}^{-1}$ in 2014 and 2015, respectively. Increasing the application of $\mathrm{N}$ fertilizer from 100 to $200 \mathrm{~kg} \mathrm{~N} \mathrm{ha}^{-1}$ was followed by an escalation of nitrate concentration in fresh rape leaf of 0.0863 and $0.0429 \mathrm{mg} \mathrm{kg}^{-1}$ in 2014 and 2015, respectively. It can be inferred from the results that for every $\mathrm{kg}$ increase in $\mathrm{N}$ fertilizer application as a side dressing there is an increase of $0.000429-$ $0.000726 \mathrm{mg}$ nitrate $\mathrm{kg}^{-1}$ of fresh rape leaf.

Temporal concentrations of nitrate in rape leaf on plots subjected to $0 ; 50 ; 100$ and $200 \mathrm{~kg} \mathrm{~N}^{-1}$ applications were significantly $(\mathrm{p} \leq 0.05)$ higher than those recorded on the control plots (Figure 4). The concentrations of nitrates in fresh leaf harvested at 77 DAT were $0.0480 \mathrm{mg} \mathrm{kg}^{-1}$ or $30 \%$; $0.0552 \mathrm{mg}$ $\mathrm{kg}^{-1}$ or $23.3 \%$; $0.0714 \mathrm{mg} \mathrm{kg}^{-1}$ or $27.3 \%$ and $0.0747 \mathrm{mg} \mathrm{kg}^{-1}$ or $24.9 \%$ in excess of those recorded in the leaf harvest at 42 DAT in plots subjected to $0 ; 50 ; 100$ and $200 \mathrm{~kg} \mathrm{~N}$ side dressing applications for the year 2014, respectively. Similarly, concentrations of fresh rape leaf nitrate harvested at 77 DAT were $0.0410 \mathrm{mg} \mathrm{kg}^{-1}$ or $24.1 \% ; 0.0594 \mathrm{mg} \mathrm{kg}^{-1}$ or $25.1 \%$; 0.0701 $\mathrm{mg} \mathrm{kg}^{-1}$ or $26.7 \%$ and $0.0416 \mathrm{mg} \mathrm{kg}^{-1}$ or $12.5 \%$ in treatment 1 ; 2; 3 and 4 plots for year 2015 respectively.

Leaf area index dynamics at leaf harvesting following applications of $N$ fertilizer

Figure 4 shows the dynamics of LAI at leaf harvesting under four application levels of $\mathrm{N}$ fertilizer side dressing. Mean separations between treatments for LAI at every harvesting event were significantly ( $\mathrm{p} \leq 0.05)$ different for both years. Mean LAI on plots amended with $50 ; 100$ and $200 \mathrm{~kg} \mathrm{~N} \mathrm{ha}^{-1}$ fertilizer exceeded mean LAI recorded on the control plots by 1.538 $(62.8 \%) ; 1.121(38.1 \%)$ and $1.603(60.0 \%)$ at harvesting events in 2014, respectively. In 2015, LAI recorded on plots that received 50; 100 and $200 \mathrm{~kg} \mathrm{~N}^{-1}$ were 0.549 (52.6\%); 1.178 $(112.9 \%)$ and $1.619(155.3 \%)$ above the LAI scored on the control plots (Figure 5). Higher LAI at leaf harvesting were observed on the $200 \mathrm{~kg} \mathrm{~N}$ fertilizer side dressing plots $(3.752-$ 3.734) for both years.

When $\mathrm{N}$ fertilizer applications were increased from 50 to 100 $\mathrm{kg} \mathrm{N} \mathrm{ha}{ }^{-1}$ LAI significantly $(\mathrm{p} \leq 0.05)$ increased by $42.6 \%(0.655)$ on average in 2014. Upgrading the $\mathrm{N}$ fertilizer application rates from 100 to $200 \mathrm{~kg} \mathrm{~N} \mathrm{ha}^{-1}$ was followed by an increase in the mean LAI at harvesting of $19.9 \%(0.441)$ in 2015 , respectively. The LAI in all experimental plots appeared to decrease considerably $(p \leq 0.05)$ from the first fresh leaf harvest at 42 DAT towards the last leaf harvest at 77 DAT in 2014 and 2015 (Figure 5). In 2014 the LAI at first leaf harvesting (42 DAT) were $1.440(275.3 \%) ; 1.799(275.9 \%) ; 2.208(228.8 \%)$ and $2.514(203.1 \%)$ in excess of the LAI recorded at the last harvesting events (77 DAT) in treatments $1 ; 2 ; 3$ and 4 plots, respectively.

The LAI at the last fresh rape leaf harvest (77 DAT) in plots subjected to $0 ; 50 ; 100$; and $200 \mathrm{~kg} \mathrm{~N} \mathrm{ha}^{-1}$ as side dressing were $0.687(193.0 \%) ; 2.209$ (358.8\%); 2.208 (228.8\%) and 2.452 $(188.6 \%)$ lower than those recorded at the first harvesting occasion (42 DAT) in 2015, respectively.

\section{Experiment 2}

\section{First harvest rape leaf yield after $N$ side dressing}

Delaying the first fresh leaf harvest by 7 (42 DAT); 14 (49 DAT) and 21 (56 DAT) days after $\mathrm{N}$ fertilizer side dressing within treatments on plots significantly $(p \leq 0.05$; Figure 6) increased the yield of first rape leaf harvest in 2014 and 2015. Generally, the fresh rape leaf harvested 14 days after $\mathrm{N}$ fertilizer side dressing in the 2014 growing season were $0.6 \mathrm{~T} \mathrm{ha}^{-1}$ $(12.6 \%) ; 1.2 \mathrm{~T} \mathrm{ha}^{-1}(21.1 \%)$ and $0.9 \mathrm{~T} \mathrm{ha}^{-1}(11.0 \%)$ in excess of 


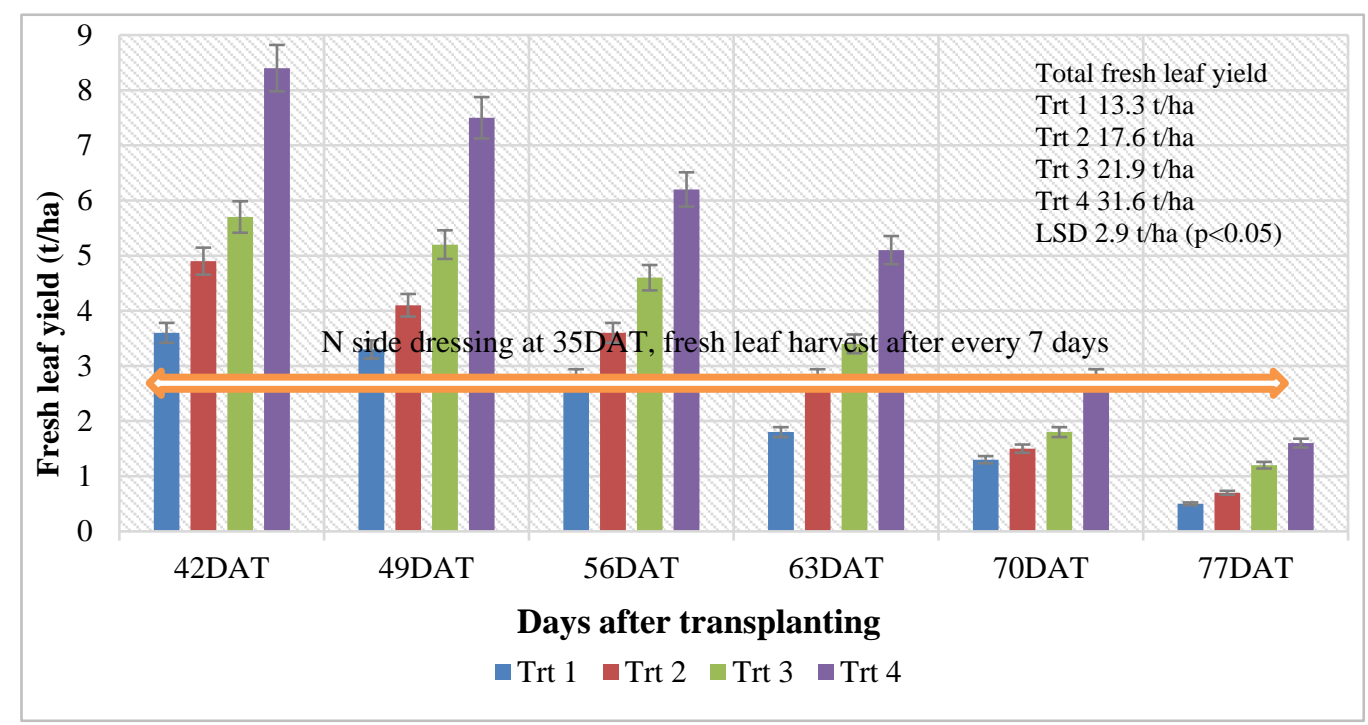

Figure 3a. Fresh rape leaf yield responses over the growing seasons after $\mathrm{N}$ fertilizer applications (2014)

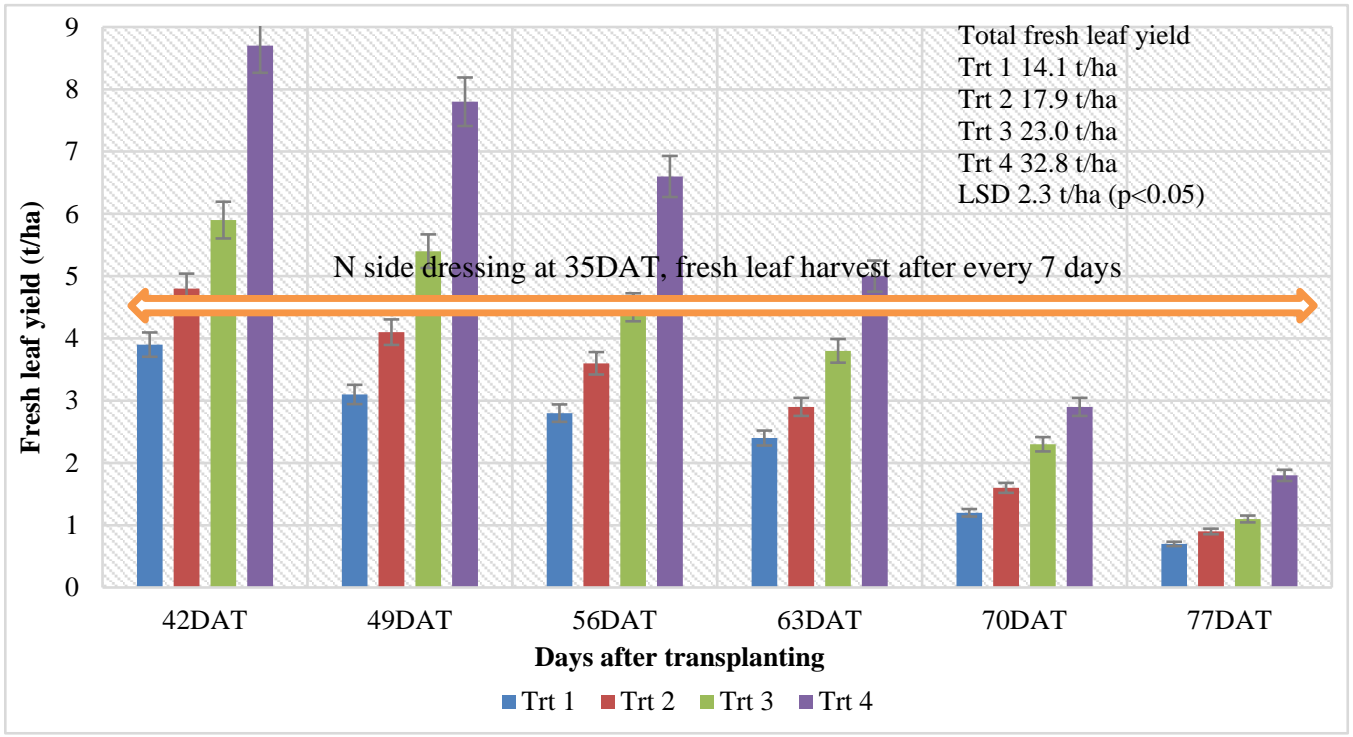

Figure 3b. Fresh rape leaf yield responses over the growing seasons after $\mathrm{N}$ fertilizer applications (2015)

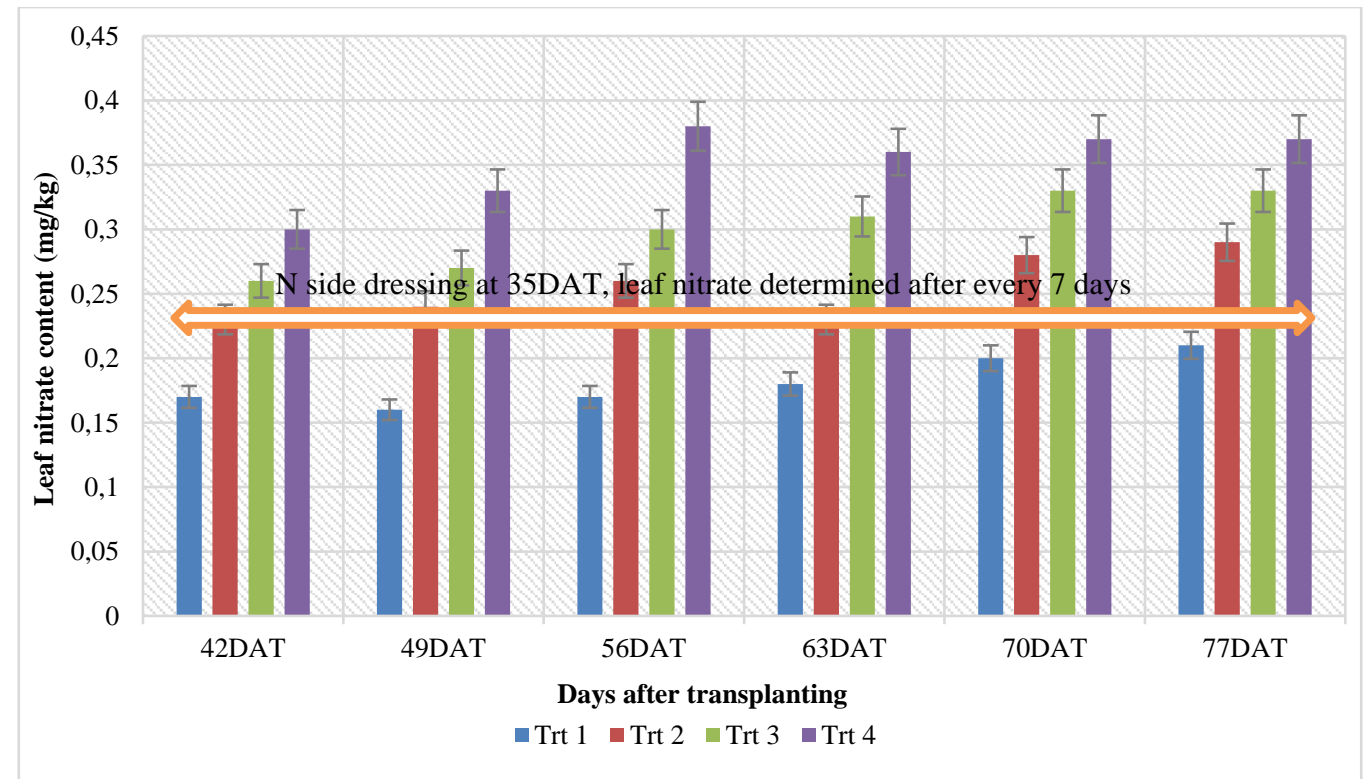

Figure 4a. Leaf nitrate content responses over the leaf harvesting period after $\mathrm{N}$ fertilizer application (2014) 


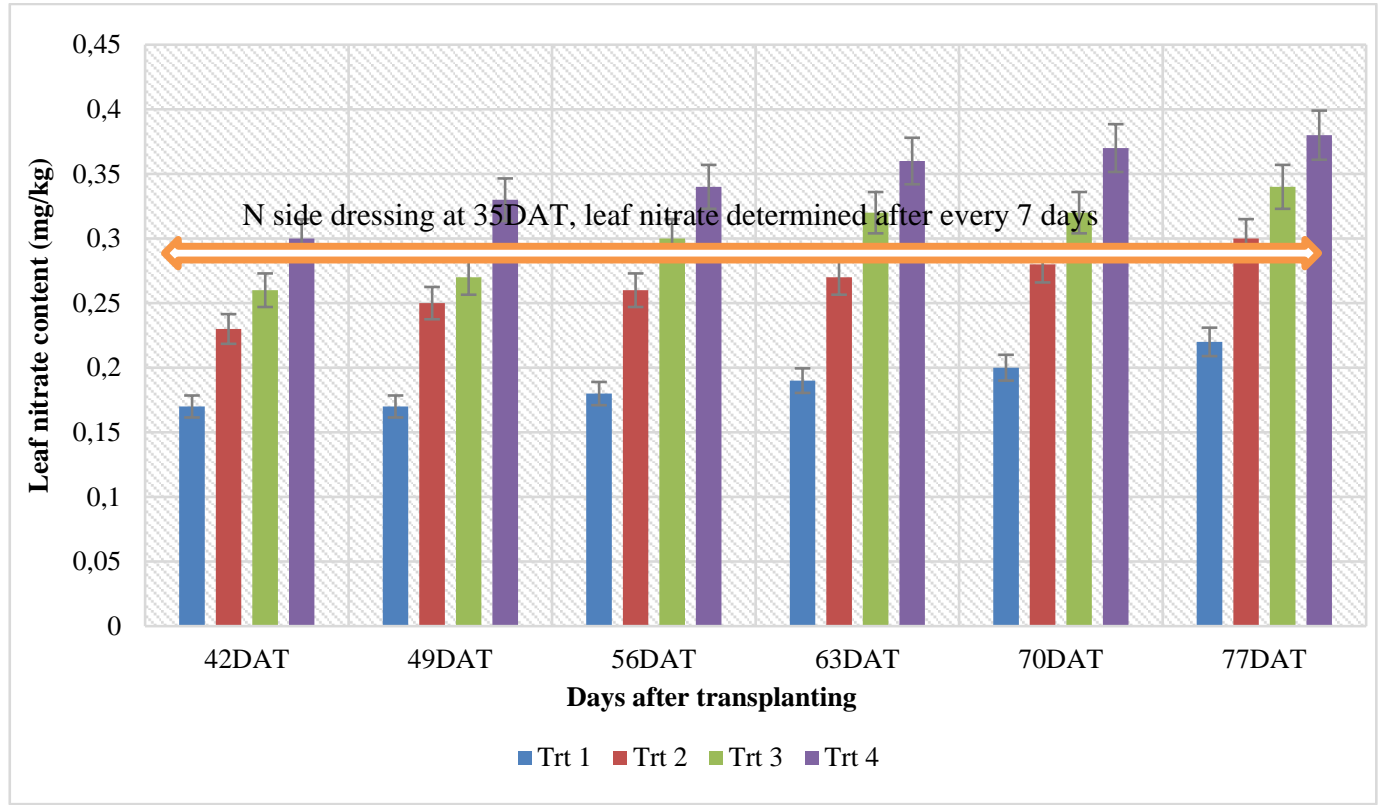

Figure 4b. Leaf nitrate content responses over the leaf harvesting period after $\mathrm{N}$ fertilizer application (2015)

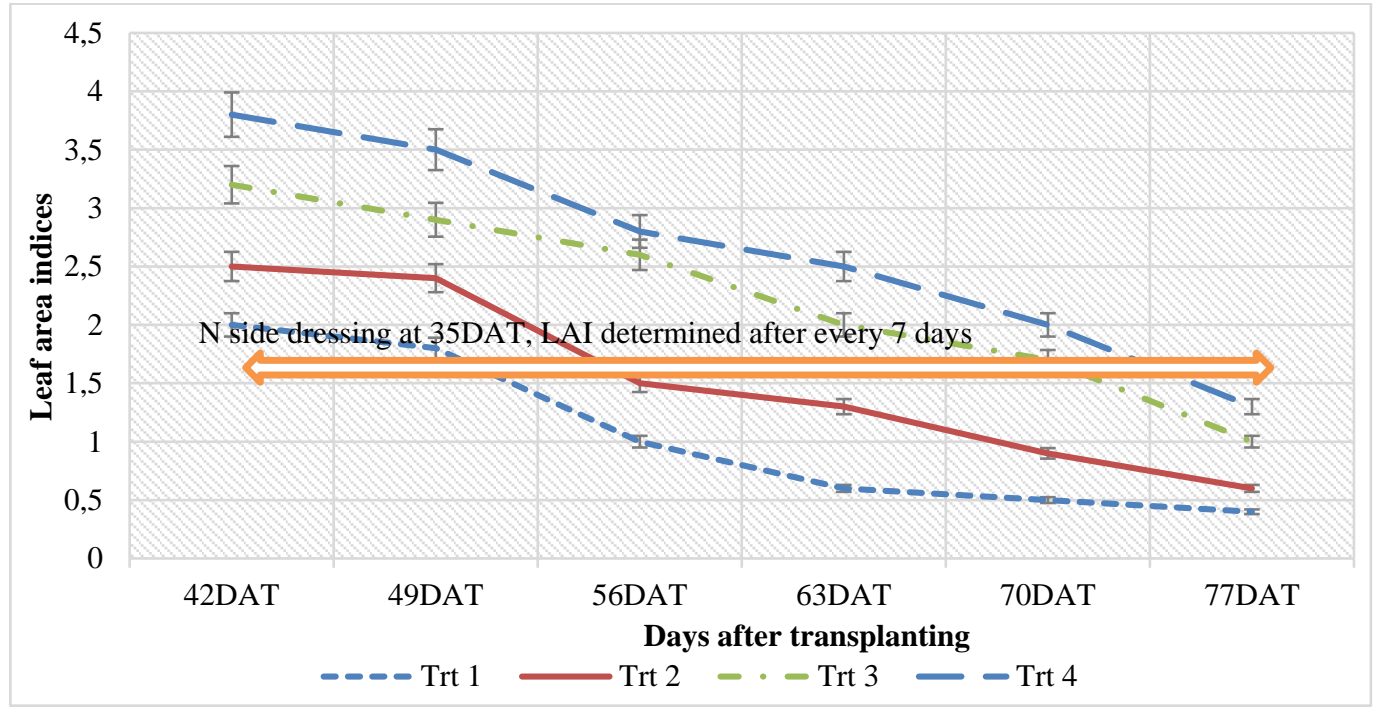

Figure 5a. Leaf area index responses over growing seasons after N fertilizer application (2014)

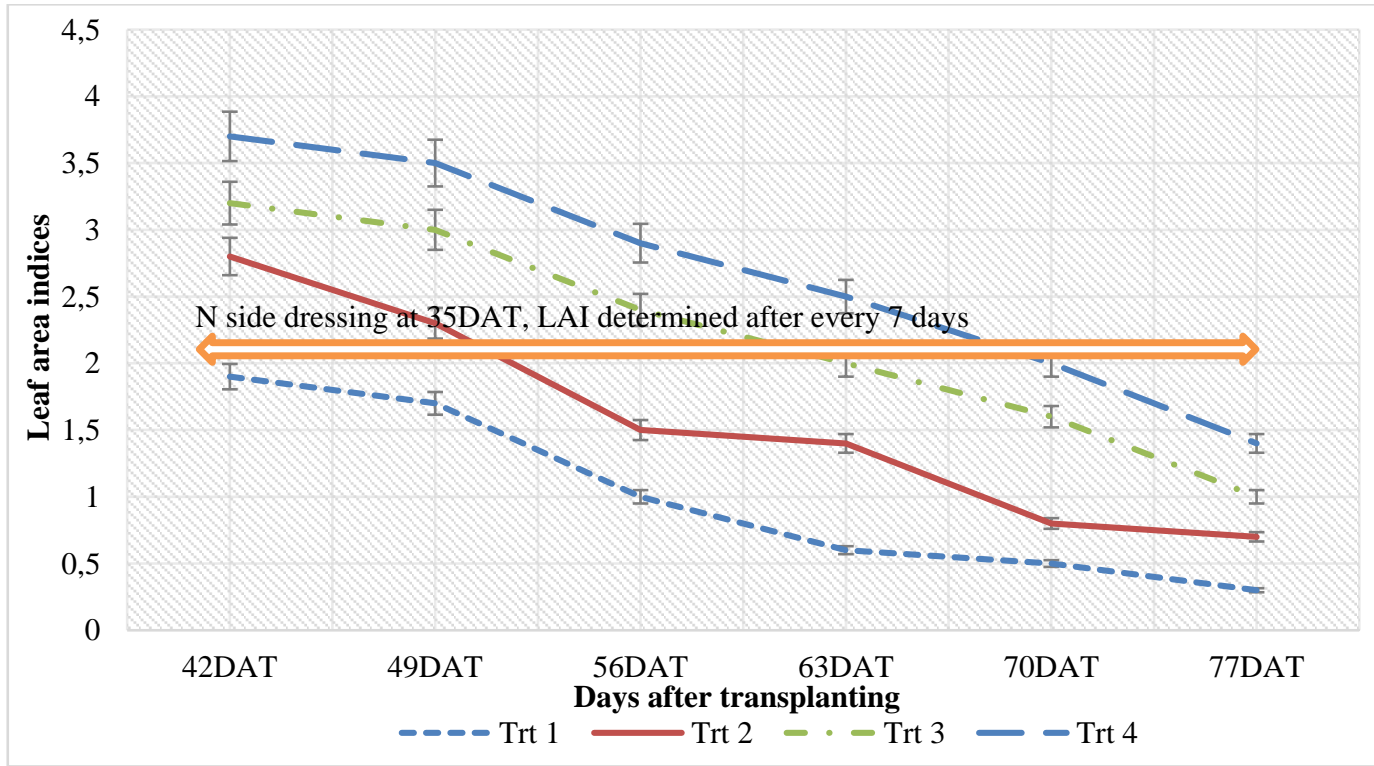

Figure $5 \boldsymbol{b}$. Leaf area index responses over growing seasons after N fertilizer application (2015) 


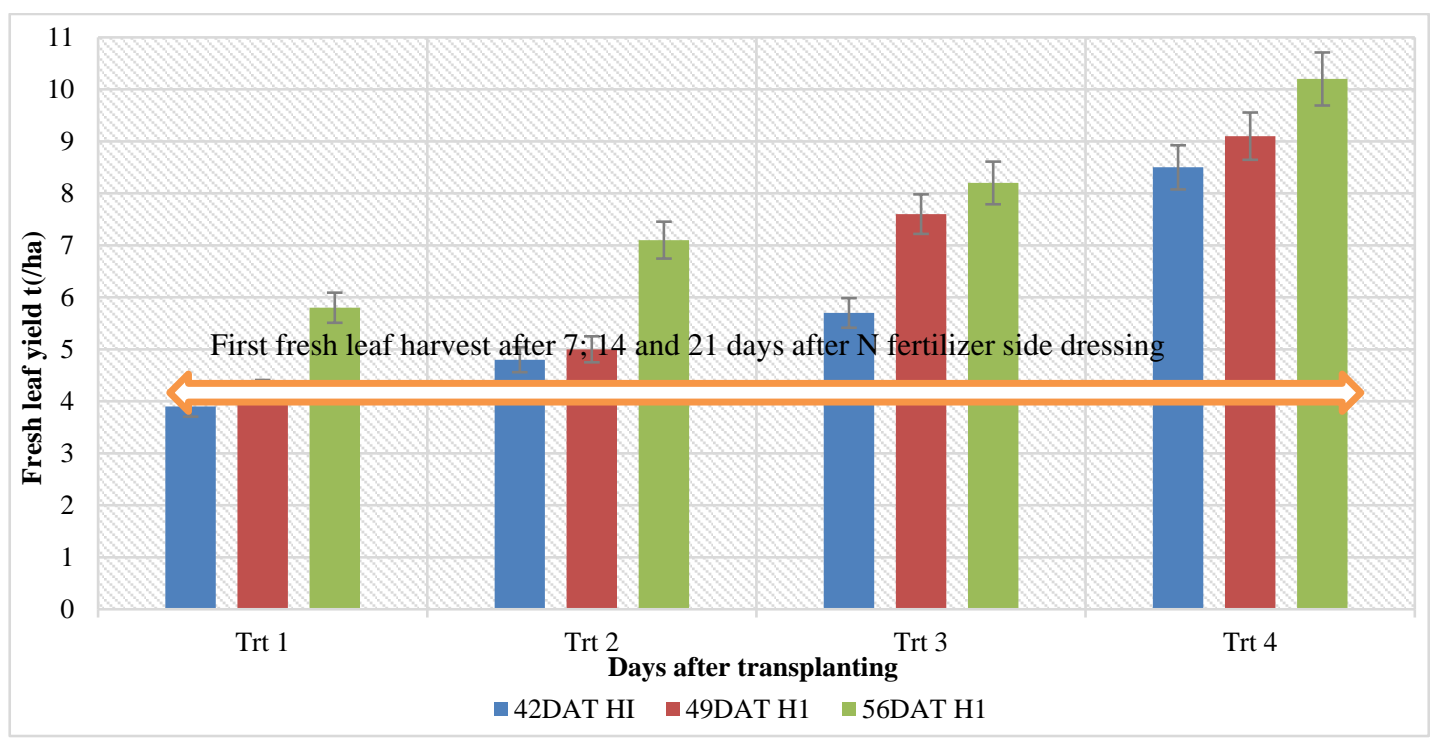

Figure 6a. Fresh leaf yield of the first harvest after N fertilizer side dressing at 35DAT (2014)

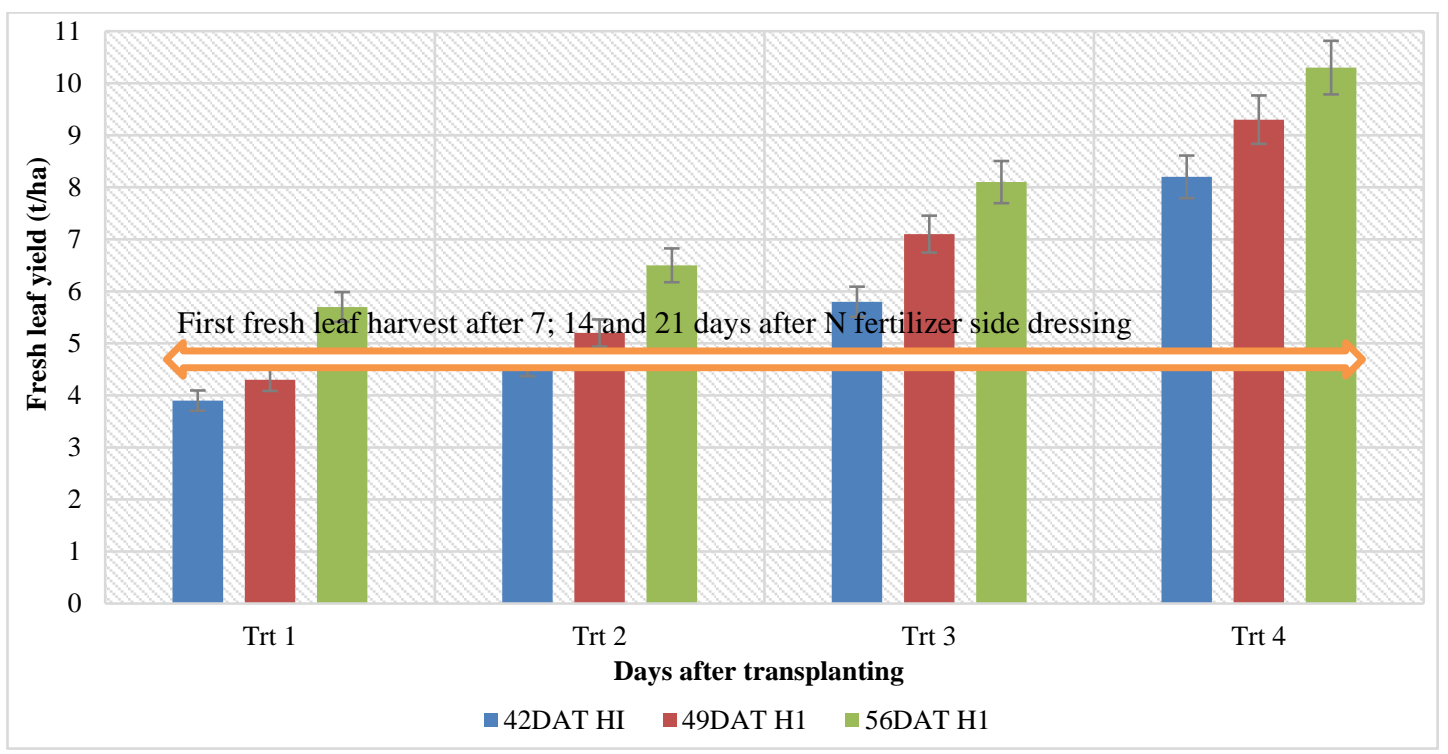

Figure 6b. Fresh leaf yield of the first harvest after N fertilizer side dressing at 35DAT (2015)

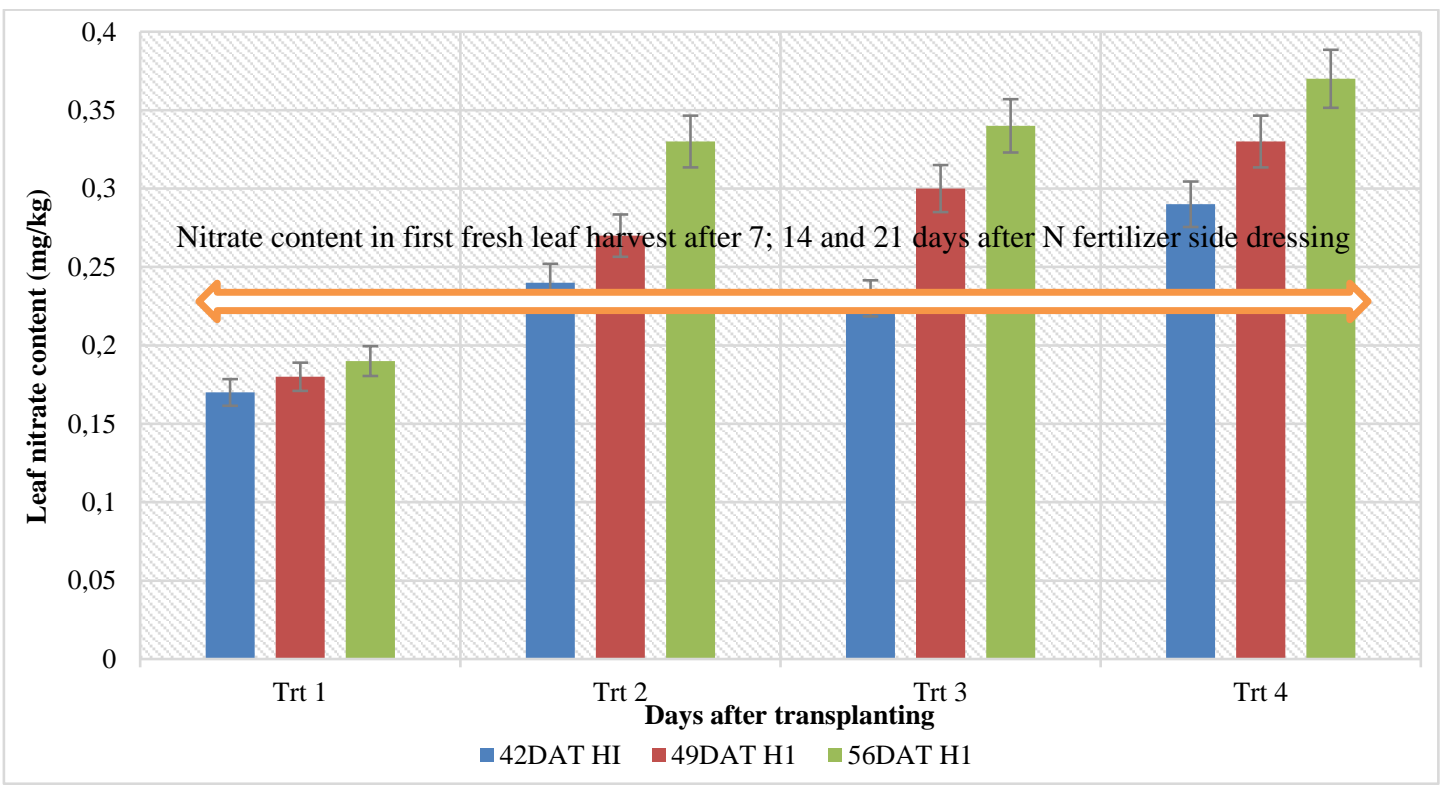

Figure 7a. Leaf nitrate content in first harvest rape leaf after N side dressing (2014) 


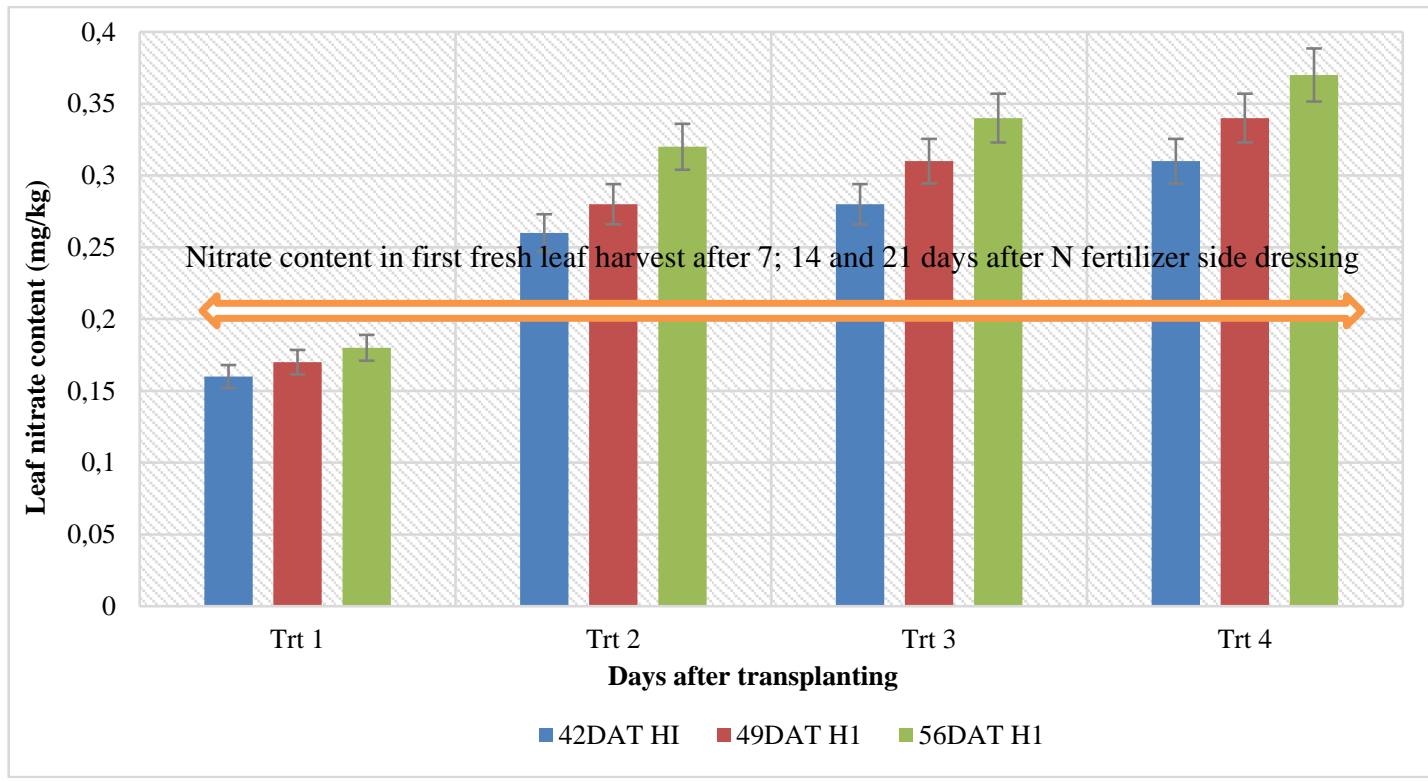

Figure $7 \boldsymbol{b}$. Leaf nitrate content in first harvest rape leaf after N side dressing (2015)

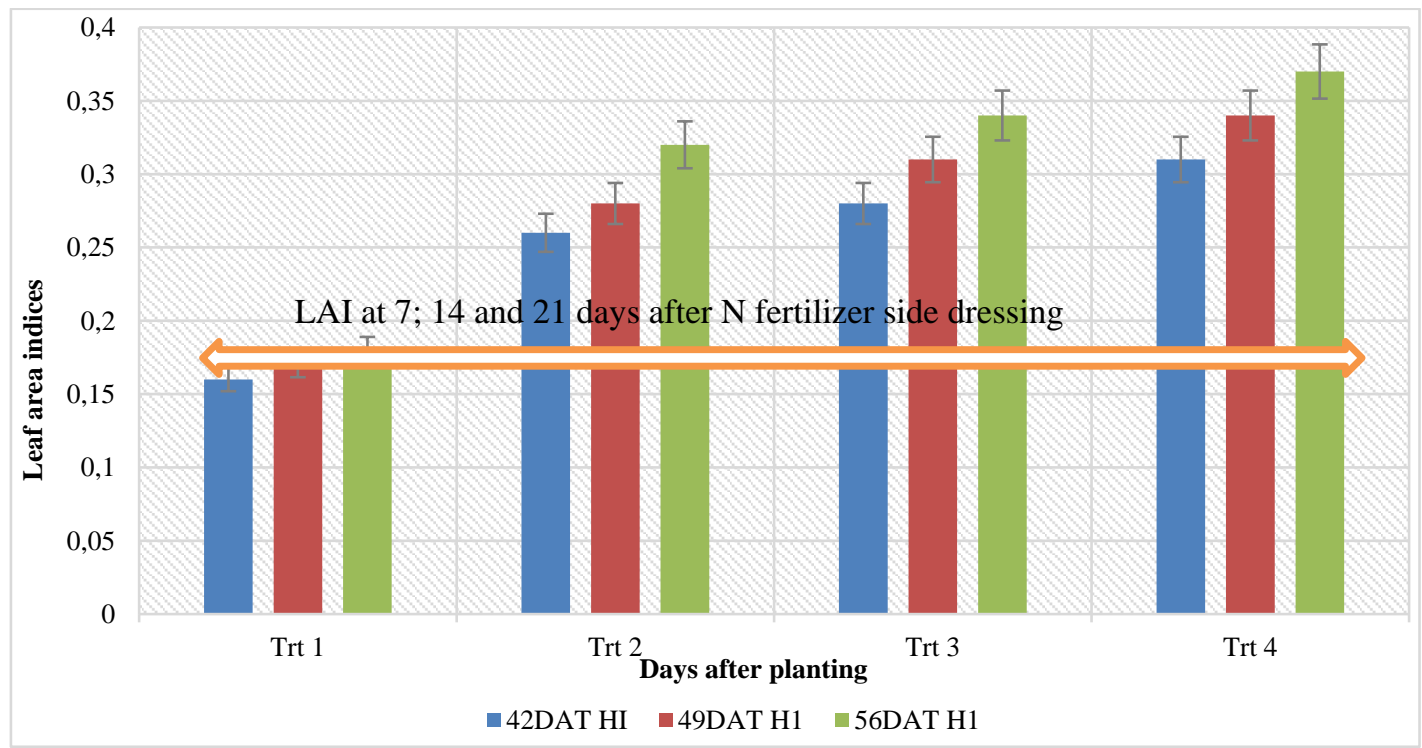

Figure 8a. LAI at 7; 14 and 21 days after N side dressing (2014)

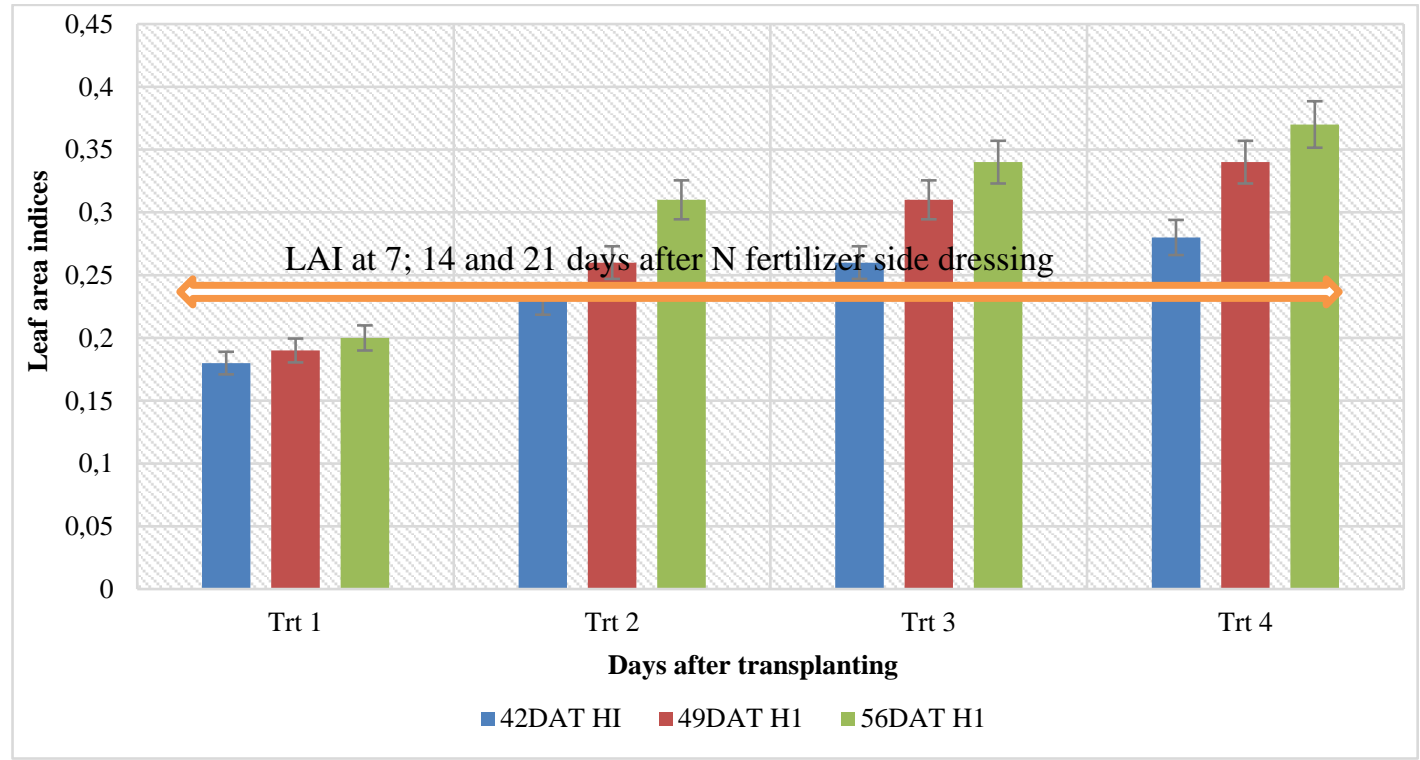

Figure $8 b$. LAI at 7; 14 and 21 days after N side dressing (2015) 
the harvest performed 7 days after $\mathrm{N}$ fertilizer side dressing for treatments $2 ; 3$ and 4 , respectively. In the same year, leaf harvests performed 21 days after application of $50 ; 100$ and $200 \mathrm{~kg} \mathrm{ha}^{-1} \mathrm{~N}$ fertilizer side dressing recorded $1.3 \mathrm{~T} \mathrm{ha}^{-1}(24.1 \%) ; 0.9 \mathrm{~T} \mathrm{ha}^{-1}$ (13.0\%) and $1.1 \mathrm{~T} \mathrm{ha}^{-1}(12.1 \%)$ fresh leaf yields above those recorded in harvests conducted 14 days after $\mathrm{N}$ fertilizer applications as side dressing. Comparatively similar trends in fresh leaf yield response to intervals between harvesting events and $\mathrm{N}$ fertilizer side dressing during the 2015 growing season (Figure 6).

\section{Nitrate concentration in first harvest of rape leaf after $N$ side} dressing

Delaying the first fresh leaf harvests by 14 days after $\mathrm{N}$ fertilizer side dressing amendments considerably escalated the concentration of nitrate in fresh rape leaves by $0.009 \mathrm{mg} \mathrm{kg} \mathrm{kg}^{-1}$ (6.2\%); $0.0337 \mathrm{mg} \mathrm{kg}^{-1}$ (13.9\%); $0.0433 \mathrm{mg} \mathrm{kg}^{-1} \leq(16.6 \%)$ and $0.0397 \mathrm{mg} \mathrm{kg}^{-1}(13.6 \%)$ above that in fresh leaves harvested 7 days after $\mathrm{N}$ fertilizer side dressing on plots subjected to $0 ; 50$; 100 and $200 \mathrm{~kg} \mathrm{~N}$ ha-1 respectively for the year 2014. In the same year, first harvests delayed by 21 days after applying $\mathrm{N}$ fertilizer top dressing had nitrate concentrations of $0.0117 \mathrm{mg}$ $\mathrm{kg}^{-1}$ (6.9\%); $0.0355 \mathrm{mg} \mathrm{kg}{ }^{-1}$ (12.9\%); $0.0378 \mathrm{mg} \mathrm{kg}^{-1}(12.4 \%)$ and $0.0407 \mathrm{mg} \mathrm{kg}^{-1}(12.3 \%)$ in excess of those recorded in first fresh leaf harvests delayed by 14 days after $\mathrm{N}$ fertilizer side dressing in treatments $1 ; 2 ; 3$ and 4, respectively. Correspondingly similar trends in nitrate accumulations in fresh rape leaf harvests was observed in 2015 experiments (Figure 7).

\section{LAI at first harvest of rape leaf after $N$ side dressing}

The period between the application of $\mathrm{N}$ fertilizer as a side dressing and the first fresh leaf harvest considerably influenced LAI $(p \leq 0.05)$ in the first leaf harvests for the 2014 and 2015 field experiments (Figure 8).

LAI progressively increased with increasing period between the application of $\mathrm{N}$ fertilizer as side dressing and the first rape leaf harvests. At 14 (49 DAT) days after $\mathrm{N}$ fertilizer amendments LAI were $0.230(11.7 \%)$; $0.537(21.9 \%) 0.671(21.0 \%)$ and $0.611(16.3 \%)$ above those recorded at first harvests conducted 7 days after $\mathrm{N}$ fertilizer top dressing on $0 ; 50 ; 100$ and $200 \mathrm{~kg} \mathrm{~N}$ $\mathrm{ha}^{-1}$ plots, respectively. When the first rape leaf harvest was delayed by 21 (56 DAT) days after $\mathrm{N}$ fertilizer side dressing the LAI increased significantly $(\mathrm{p}<0.05)$ by $0.427(19.3 \%) ; 0.435$ (14.6\%); $0.500(13.0 \%)$ and $0.505(11.6 \%)$ above those recorded at first harvest conducted 14 (49 DAT) days after $\mathrm{N}$ fertilizer amendments in treatments $1 ; 2 ; 3$ and 4 plots, respectively.

Delaying the first harvests of rape leaf by 21 days after conducting $\mathrm{N}$ fertilizer side dressing escalates rape LAI by 0.657 $(33.2 \%) ; 0.972(39.7 \%) ; 1.171(36.7 \%)$ and $1.116(29.8 \%)$ above those observed at harvests delayed by 7 (42 DAT) days after $\mathrm{N}$ fertilizer amendments in treatment $1 ; 2 ; 3$ and 4 plots respectively for the years 2014 .

\section{Regression analyses between measured variables}

Figures 9-10 show the regression analyses indicating the direct effects of fresh rape leaf nitrate concentrations and LAI on harvested rape leaf yield. The regression analysis has shown that the LAI and fresh rape yield were significantly $(\mathrm{p} \leq 0.05)$ correlated with $r^{2}$ values (coefficients of determination) ranging from $0.90-0.92$. However, the relationship between fresh rape leaf nitrate concentration and rape leaf yield did not show significant correlation $(p>0.05)$ with coefficients of determination of 0.04 .

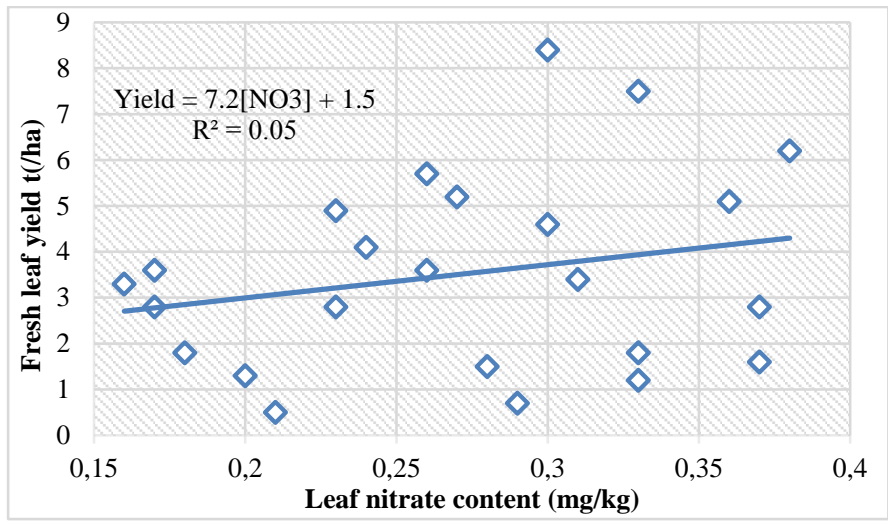

Figure 9a. Regression analysis between fresh rape leaf yield and leaf nitrate (2014)

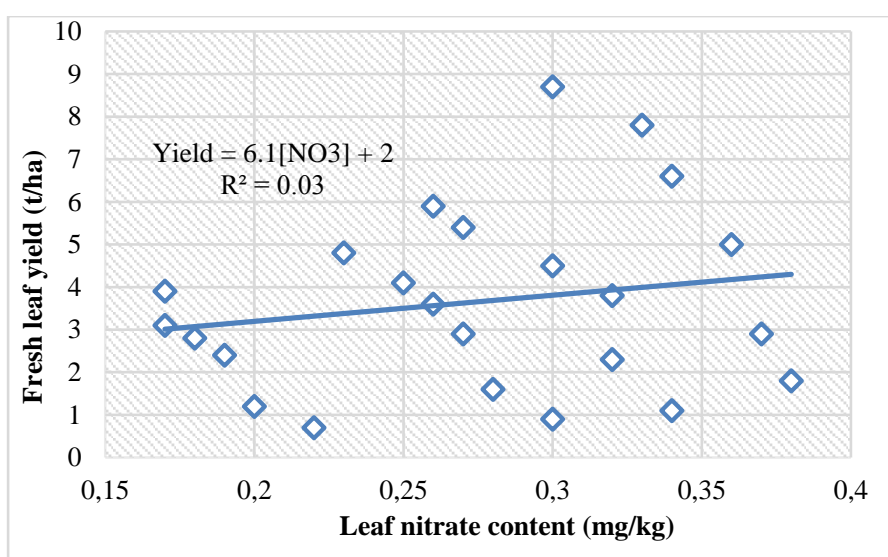

Figure $9 b$. Regression analysis between fresh rape leaf yield and leaf nitrate (2015)

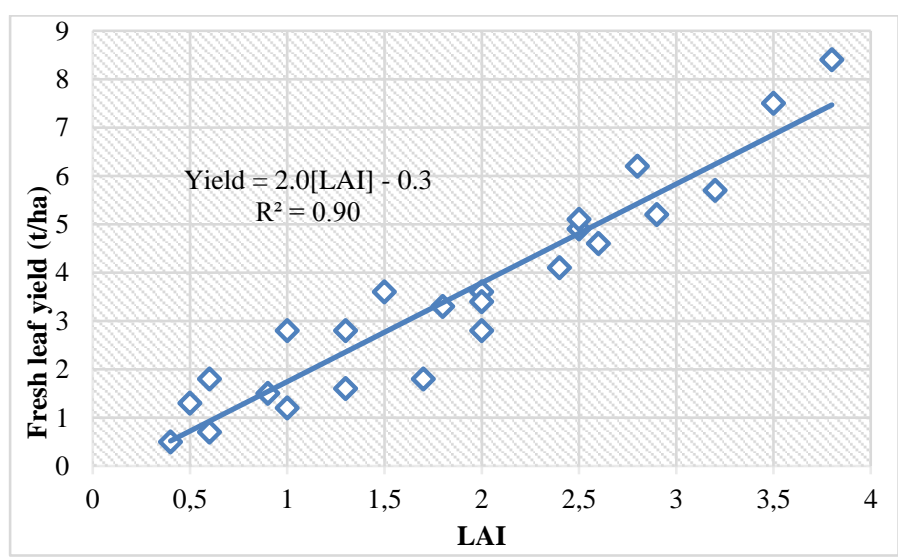

Figure 10a. Regression analysis between fresh rape leaf yield and LAI (2014)

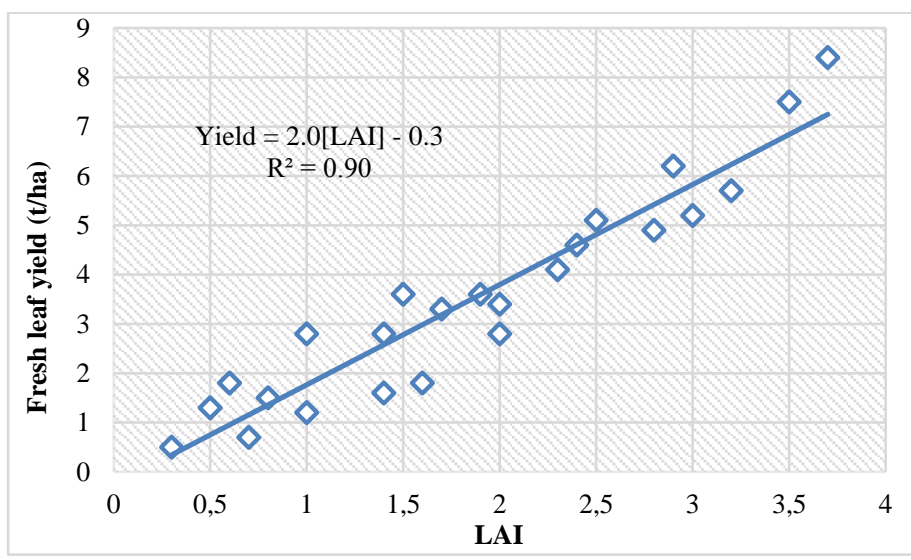

Figure 10b. Regression analysis between fresh rape leaf yield and LAI (2015) 


\section{Discussion}

\section{Experiment 1}

Fresh rape leaf yield responses over the growing seasons after $N$ fertilizer applications

In the current study, higher fresh leaf weights recorded on plots amended with higher rates of $\mathrm{N}$ fertilizer are attributed to increased photosynthetic processes (Johnson et al., 2010), leaf area production and net $\mathrm{N}$ assimilation rate (Bouchet et al., 2016). Similar responses to $\mathrm{N}$ fertilizer applications to leaf rape yield were reported by Rathore \& Manohar (1989). These studies reported a generally linear increase in rape biomass with increased $\mathrm{N}$ side dress from $30 \mathrm{~kg} \mathrm{~N} \mathrm{ha}^{-1}$ to $120 \mathrm{~kg} \mathrm{ha}^{-1}$. Singh et al. (2006) established linear increases in rape yield up to $\mathrm{N}$ $180 \mathrm{~kg} \mathrm{ha}^{-1}$. The successive reductions in fresh rape leaf harvest yield towards the last harvest are attributed to the depletions of available $\mathrm{N}$ as the period from the $\mathrm{N}$ side dressing event increases.

Leaf nitrate content dynamics over the harvesting period following applications of $N$ fertilizer

Field leaf rape is generally characterized by high levels of nitrate extraction from the soil and, in certain circumstances, even above its requirements (Rossato et al., 2002; Bouchet et al., 2016). The current study has recorded consistently higher leaf nitrate concentrations with increasing $\mathrm{N}$ fertilizer applications (Figure 4). Excessive concentrations of nitrate in rape leaves are harmful to human health (Rossato et al., 2002). Related studies have shown that nitrate $\mathrm{N}$ is the most critical form in leaf biomass due to its potential toxicity to livestock and humans (Stopes et al., 1989). In addition, higher leaf concentrations of nitrate $\mathrm{N}$ causes bitterness in rape leaves, making them less acceptable for consumption (Maereka et al., 2007; Gonzalez et al., 2016). Research results have indicated that fresh vegetables are a major exogenous source of inorganic nitrates and nitrites in human diets. Experimental evidence has shown that nitrogen plays an important role in plant growth and development due to its content in proteins; nucleic acids, chlorophyll; enzymes and hormones (Rathke et al., 2006; Anjum et al., 2012). In a related study on leaf senescence and $\mathrm{N}$ remobilization in the rape crop Avice \& Etienne (2014) reported a strong response in rape leaf nitrate content to $\mathrm{N}$ fertilizer amendments.

Results of the study have shown that the concentration of leaf nitrate increased consistently after every successive fresh leaf harvest (Figure 3). The observed trend in leaf nitrate content dynamics is attributable to the reduction of the above ground plant biomass removed in every harvest that could have assimilated the nitrate from the soil ambience. The increase in nitrate nitrogen concentration in biomass with time in the current experiment is in direct contrast with Brown et al. (1999) who, in a study on nitrate accumulation in a vegetable biomass, reported that nitrates are generally higher in early vegetative growth when compared with more mature plant biomass. In a related study on nitrogen fertilization and timing of harvesting on leaf nitrate content and taste in fresh leaf rape Maereka et al. (2007) reported increasing fresh leaf harvests and leaf nitrate content with increasing fertilizer rates accompanied by bitterness of leaves. Results of the current study may imply that delayed harvesting of fresh rape leaf is accompanied by higher leaf nitrate content. The toxicity of nitrates in animal cell metabolism emanates from the fact that it is degraded into much more toxic nitrites (Bouchet et al., 2016), which is ten times more toxic than nitrates in the human body (Terry et al., 2001; Gonzalez et al., 2016).

Leaf area index dynamics at leaf harvesting following applications of $N$ fertilizer

In the current study, the application of higher rates of $\mathrm{N}$ were accompanied by rapid leaf area growth and improved overall crop nitrogen assimilation and thus contributing to increased fresh leaf yield (Li et al., 2016). The supply of $\mathrm{N}$ is a limiting factor in leaf rape production as it influences the growth of leaf area which impacts on yield if sustained throughout the growing season (Roggatz et al., 1999; Reid, 2002; Nyakudya et al., 2010).

The higher LAI recorded on plots subjected to higher $\mathrm{N}$ fertilizer side dressing are a result of increased mineral $\mathrm{N}$ extraction from a soil with high replenishments of available $\mathrm{N}$. The decrease in LAI displayed by the rape crop in all treatments with time in this experiment confirm conclusions arrived at by $\mathrm{Li}$ et al. (2016). In a study on rape plant development response to $\mathrm{N}$ fertilizer application the researchers recorded increasing rape leaf area growth with increasing $\mathrm{N}$ fertilizer application rate.

\section{Experiment 2}

\section{First harvest rape leaf yield after $N$ side dressing}

Leaf rape yield increase is the ultimate outcome of improved soil fertility management which depends considerably on $\mathrm{N}$ fertilization strategy. In the current study, fresh rape leaf yield in the first harvest after $\mathrm{N}$ fertilizer side dressing increased with increasing delay period after $\mathrm{N}$ fertilizer side dressing. The growth and yield of rape are enhanced significantly by increasing the period of interaction between the soil ambience and plant root systems at the root/soil interface. For this reason, in each set of treatments, the yield of rape leaf in the first harvest after applying $\mathrm{N}$ fertilizer side dressing was highest at 21 days after applying the $\mathrm{N}$ fertilizer side dressing (56 DAT, Figure 5).

This implies that delaying rape leaf harvest after $\mathrm{N}$ fertilizer side dressing can be used as a strategy to boost rape leaf yield for vegetable markets with high single delivery demand. Nitrate content in first harvest rape leaf after $\mathrm{N}$ side dressing Results have demonstrated that when the first harvest of fresh rape leaf is delayed by 7 (42 DAT); 14 (49 DAT) and 21 (56 DAT) days after application of $\mathrm{N}$ fertilizer side dressing the content of nitrates in rape leaves considerably increase (Figure 6).

Nitrate concentration in first harvest of rape leaf after $N$ side dressing

In a related study, the taste of fresh rape leaf was found to get bitterer with increasing nitrate concentrations in leaves (Brown et al., 1999; Anjana \& Iqba, 2006). In its characteristic $\mathrm{N}$ absorption pattern, a leaf rape plant accumulates most of the $\mathrm{N}$ in the leaves which can be as high as $7 \%$ of the mass of leaves resulting in a substantial proportion of $\mathrm{N}$ as storage $\mathrm{N}$ (Iammarino et al., 2014). Previous research results have indicated that there are large amounts of amino acids found in fresh rape leaves (Roggatz et al., 1999) associated with higher concentrations of nitrate in fresh leaves.

While a delayed first harvest of fresh rape leaves after $\mathrm{N}$ fertilizer side dressing increases opportunities for harvesting 
higher leaf yield, the delayed first harvest contains escalated concentrations of nitrate.

\section{LAI at first harvest of rape leaf after $N$ side dressing}

Various recent studies have shown that the size of rape leaves is largely determined by the nutritional status of the soil in which the plant grows (Li et al., 2016). The LAI, which is defined as the average leaf per unit of land, appear to respond positively with increasing application rates of $\mathrm{N}$ fertilizer. The LAI is an integral part of chlorophyll, a primary absorber of electromagnetic radiation energy needed for photosynthesis (Bahar et al., 2017). The daily biomass production in rape is the product of the amount of radiation intercepted by the canopy and critical radiation use efficiency (Johnson et al., 2010).

\section{Regression analyses between measured variables}

The concentrations of nitrate in fresh rape leaf and rape LAI are important predictors of fresh rape leaf yield under field conditions. The fact that the coefficients of regression for the relationships between leaf nitrate content and fresh rape leaf are considerably lower $\left(\mathrm{r}^{2}=0.04\right)$ than the coefficients of determination for the relationships between LAI and rape yield $\left(\mathrm{r}^{2}\right.$ values between 0.90 and $0.92, \mathrm{p}<0.05$; Figure 8$)$ shows that leaf area index is a stronger determinant of rape leaf yield. This implies that the fresh rape yield can be more accurately predicted by values of rape LAI. Nitrate concentrations in fresh rape leaf is a poor predictor of rape yield under field conditions.

\section{Conclusions}

Increased rates of $\mathrm{N}$ fertilizer application have the effect of considerably improving the yield of fresh rape leaf; LAI and elevates concentration of leaf nitrate. When harvesting is deliberately delayed after $\mathrm{N}$ fertilizer application rape LAI are significantly increased. Delaying the first leaf harvests by $7 ; 14$ and 21 days after $\mathrm{N}$ fertilizer side dressing amendments increases the content of nitrate in fresh rape leaves. Delaying rape leaf harvest after $\mathrm{N}$ fertilizer side dressing can be used as a strategy to boost rape leaf yield for vegetable markets with high single delivery demand. Fresh rape yield can be more accurately predicted by values of rape LAI. Nitrate concentrations in fresh rape leaf is a poor predictor of rape yield under field conditions.

\section{References}

Anjana, S.U., Iqba, M. (2006): Nitrate accumulation in plants, factors affecting the process, and human health implications: A review. Agronomy for Sustainable Development 27: 45-57. DOI: 10.1051/agro:2006021.

Anjum, A., Gill, S.S., Umar, S., Ahmad, I., Duarte, A.C., Pereira, E. (2012): Improving growth and productivity of Oleiferous Brassicas under changing environment: Significance of $\mathrm{N}$ and $\mathrm{S}$ nutrition, and underlying mechanisms. Scientific World Journal: 1-12. http://dx.doi.org/10.1100/ 2012/657808.

Avice, J.C., Etienne, P. (2014): Leaf senescence and N remobilization efficiency in oilseed rape (Brassica napus L.). JXB 65: 3813-3824. DOI:10.1093/jxb/eru177.

Bahar, N.H., Ishida, F.Y., Weerasinghe, L.K. et al. (2017): Leaf-level photosynthetic capacity in lowland Amazonian and high-elevation Andean tropical moist forests of Peru. New Phytologist. 214: 1002-1018. doi: 10.1111/nph.14079.

Beeves, L., Hageman, R.H. (1983): Uptake reduction of nitrate. Bacteria and higher plants. In: Laudhli A, Bieleski RC, eds. Encyclopedia of Plant Physiology, New Series. 15A: 351-375.

Black, G. G., Hartge, K. H. (1986): Bulk density. Methods of soil analysis. Part 3 ASA Madison, WI.

Bouchet, A.S., Laperche, A., Bissuel-Belaygue, C., Snowdon, R., Nesi, N., Stahl, A. (2016): Nitrogen use efficiency in rapeseed. A review. Agronomy for Sustainable Development 36: $1-20$.

Bouyoucos, G. J. (1965): Hydrometer method improved for making particle size analysis of soils. Agronomy Journal 27: 738-741.

Bremner, J.M. (1996): N total. In: Sparks D L, eds. Methods of soil analysis: Part 3. Chemical methods, (Number 5) in the Soil Science Society of America. Book series Soil Science Society of America, Inc., American Society of Agronomy, Inc., Madison, Wisconsin, USA, pp 1085 - 1121.

Brown, J.R., Marshall, C., Smith, G.E. (1999): Nitrate accumulation in vegetable crops as influenced by soil fertility practices. Missouri Agricultural Experiment Station Research Bulletin. 920:1-23.

Cataldo, D.A., Haroon, M., Schrader, L.E., Youngs, V.L. (1975): Rapid colorimetric determination of nitrate in plant tissue by nitration of salicylic acid. Communications in Soil Science and Plant Analysis 6: 71-80.

Chakwizira, E., Johnstone, P., Fletcher, A.L., Meenken, E.D. (2014): Effects of $\mathrm{N}$ rate on nitrate $-\mathrm{N}$ accumulation in forage kale and rape crops. Grass and Forage Science 70(2): 268-282. https://doi.org/10.1111/gfs.12109.

Daubresse, C.M., Vedele, F.D., Deehorgnet, J., Chardon, F., Gaufichon, L., Suzuki, A. (2010): N uptake, assimilation and remobilization in plants: challenges for sustainable and productive agriculture. Annals of Botany. 105 (7): 1141-1157. https://doi.org/10.1093/aob/mcq028.

De Lannoy, G. (2001): Vegetables: Pumpkins. In: Raemaekers $\mathrm{RH}$ (ed) Crop production in tropical Africa. Directory General for International Cooperation (DGIC). Brussels, Belgium, pages 459 - 461. DOI:10.1007/s40003-014-0147-1.

FAO-ISS-ISRIC (1998): World Reference Base for Soil Resources. World Soil Resource Report 84. FAO, Rome.

GenStat (2003): GenStat for Windows (7th Edition) Introduction. Hemel Hempstead: VSN International.

Gonzalez, A., Hyde, E., Sangwan, N., Gilbert, J.A., Viirre, E., Knight, R. (2016): Migraines are correlated with higher levels of nitrate-, nitrite-, and nitric oxide-reducing oral microbes in the American Gut Project Cohort. Systems 1(5): 105-116. 1:e00105-00116. 10.1128/mSystems.00105-16.

Hirel, B., Le Gouis, J., Ney, B., Gallais, A. (2007): The challenge of improving $\mathrm{N}$ use efficiency in crop plants: towards a more central role for genetic variability and quantitative genetics within integrated approaches. JXB. 58: 2369-2387. DOI:10.1093/jxb/erm097.

Iammarino, M., Di Taranto, A., Cristino, M. (2014): Monitoring of nitrites and nitrate levels in leafy vegetables (spinach and lettuce): a contribution to risk assessment. Journal 
of the Science of Food in Agriculture 15:773-8. DOI:10.1002/jsfa.6439.

Johnson, I.R., Thornley, J.H., Frantz, J.M., Bugbee, B. (2010): A model of canopy photosynthesis incorporating protein distribution through the canopy and its acclimation to light, temperature and $\mathrm{CO}_{2}$. Annals of Botany. 106: 735-749. DOI:10.1093/aob/mcq183

Joshipura, K.J., Hu, F.B., Manson, J.E. (2001): The effect of fruit and vegetable intake on risk for coronary heart disease. Annals of Internal Medicine 134:1106-1114. DOI:10.7326/0003-4819-134-12-200106190-00010.

Kuntashula, E., Mafongoya, P.L., Sileshi, G., Lungu, S. (2004): Potential of biomass transfer technologies in sustaining vegetable production in the wetlands (dambos) of eastern Zambia. Experimental Agriculture 40: 37-51.

Kusumi, K., Hirotsuka, S., Shimada, H., Chono, Y., Matsuda, O., Iba, K. (2010): Contribution of chloroplast biogenesis to carbon-nitrogen balance during early leaf development in rice. Journal of Plant Research 123: 617-622. DOI:10.1007/s10265-009-0277-X.

Li, X., Li, Q., Yang, T., Nie, Z., Chen, G., Hu, L. (2016): Responses of plant development, biomass and seed production of direct sown oilseed rape (Brassica napus) to nitrogen application at different stages in Yangtze River Basin. Field Crops Research 194: 12-20.

Maereka, E.K., Madakadze, R.M., Mashingaidze, A.B., Kageler, S., Nyakanda, C. (2007): Effect of $\mathrm{N}$ fertilization and timing of harvesting on leaf nitrate content and taste in mustard rape (Brassica juncea L. Czern). Journal of Food Agriculture and Environment 5 (3 \& 4):285 - 290.

Masaka, J. \& Ndhlovu, S. (2007): The effect of different forms of water hyacinth (Eichhornia crassipes) organic fertilizers on leaf growth rate and yield of rape (Brassica napus). International Journal of Agricultural Research. 2: 254-260. DOI:10.3923/ijar.2007.254.260.

McCall, D., Willumsen, J. (1998): Effects of nitrate, ammonium and chloride application on the yield and nitrate content of soil-grown lettuce. Journal of Horticultural Science and Biotechnology 33:134-5. https://doi.org/10.1080/ 14620316.1998.11511036.

Nelson, D. W., Sommers, L. E. (1996): Methods of determination of total organic carbon (TOC) in soils and sediments. In: Page AL ed. Total C, organic C and organic matter. Ecological Risk Assessment Center, Office of Research and Development, US. Environmental Protection Agency, Las Vegas, pp 456-691 461.

Nyakudya, I.W., Jimu, L., Marashe, M., Katsvanga, C.A.T. (2010): Comparative growth and yield responses of rape (Brassica napus L.) to different soil fertility management amendments. Electronic Journal of Environmental, Agricultural and Food Chemistry 9(1): 207-214.
Oldham, C.H. (1999): Brassica crops and allied Cruciferous crops. Biotech Books; Delhi.

Phillips, W.E.J. (2005): Changes in the nitrate and nitrite contents of fresh and processed spinach during storage. J Agric Food Chem. 16 (1): 88-91. DOI: 10.1021/jf60155a012.

Rathke, W.I., Behrens, T., Diepenbrock, W. (2006): Integrated $\mathrm{N}$ management strategies to improve seed yield, oil content and $\mathrm{N}$ efficiency of winter oilseed rape (Brassica napus L.): A review. Agriculture, Ecosystems \& Environment. 117: 2 (3) 80-108. doi.org/10.1016/j.agee.2006.04.006.

Rathore, P.S., Manohar, S.S. (1989): Response of mustard to nitrogen and sulphur. Effect of nitrogen and sulphur on ancillary characters and yield of mustard. Indian J Agron. 34(3): 333-336.

Reid, J.B. (2002): Yield response to nutrient supply across a wide range of conditions. Model derivation. Field Crops Research. 77: 161- 171. DOI:10.1016/S0378-4290(02)00087-4.

Roggatz, U., McDonald, A.J., Stadenberg, I., Schurr, U. (1999): Effects of nitrogen deprivation on cell division and expansion in leaves of Ricinus communis L. Plant, Cell and Environment 22: 81-89. https://doi.org/10.1046/j.13653040.1999.00383.x.

Rossato, L., MacDuff, J.H., Laine, P., Le Deunff, E., Ourry, A. (2002): $\mathrm{N}$ storage and remobilization in Brassica napus L. during the growth cycle: effects of methyl jasmonate on nitrate uptake, senescence, growth, and VSP accumulation. Journal of Experimental Botany 53: 1131-1141. https://doi.org/ 10.1093/jexbot/53.371.1131.

Schjoerring, J.K., Bock, J.G., Gammelvind, L., Jensen, C.R., Mogensen, V.O. (1995): $\mathrm{N}$ incorporation and remobilization in different shoot components of field-grown winter oilseed rape (Brassica napus L.) as affected by rate of $\mathrm{N}$ application and irrigation. Plant and Soil 177: 255-264. DOI:10.1080/ 01904167.2010.489983.

Singh, T., Dahiya, K.S., Sidhu, M.S. (2006): Effect of genotype, seedling age and row spacing on performance of transplanted African mustard (Brassica carinata) under latesown condition. Indian Journal of Agronomy 51(3): 221-224.

Stopes, C., Woodward, L., Forde, G., Vogtmann, H. (1989): Effect of composted farmyard manure and a compound fertilizer on yield and nitrate accumulation in three summer lettuce cultivars grown in an organic system. Agriculture Ecosystems \& Environment 27(1-4):555-560. DOI:10.1016/0167-8809(89) 90116-3.

Terry, P., Terry, J.B., Wolk, A. (2001): Fruit and vegetable consumption in the prevention of cancer: An update. Journal of Internal Medicine 250: 280-290. https://doi.org/ 10.1111/j.1365-2796.2001.00886.x.

Vincent, V., Thomas, R.G. (1960): An Agricultural Survey of Southern Rhodesia, Part I Agro-Ecological Survey, Government Printers, Salisbury. 